UDC 577.112.7

\title{
MULTIPLE MOLECULAR FORMS OF ADAPTOR PROTEIN RUK/CIN85 SPECIFICALLY ASSOCIATE WITH DIFFERENT SUBCELLULAR COMPARTMENTS IN HUMAN BREAST ADENOCARCINOMA MCF-7 CELLS
}

\author{
B. O. VYNNYTSKA-MYRONOVSKA ${ }^{1}$, Ya. P. BOBAK ${ }^{1}$, G. V. PASICHNYK ${ }^{2}$, \\ N. I. IGUMENTSEVA' ${ }^{1}$, A. A. SAMOYLENKO' , L. B. DROBOT ${ }^{2}$ \\ ${ }^{1}$ Institute of Cell Biology, National Academy of Sciences of Ukraine, Lviv; \\ ${ }^{2}$ Palladin Institute of Biochemistry, National Academy of Sciences of Ukraine, Kyiv; \\ e-mail:drobot@biochem.kiev.ua
}

Ruk/CIN85 is a receptor-proximal 'signalling' adaptor that possesses three SH3 domains, Pro- and Ser-rich regions and C-terminal coiled-coil domain. It employs distinct domains and motifs to act as a transducer platform in intracellular signalling. Based on cDNA analysis, various isoforms of Ruk/CIN85 with different combination of protein-protein interaction domains as well as additional Ruk/CIN85 forms that are the products of post-translational modifications have been demonstrated. Nevertheless, there is no precise information regarding both the subcellular distribution and the role of Ruk/CIN85 multiple molecular forms in cellular responses. Using MCF-7 human breast adenocarcinoma cells and cell fractionation technique, specific association of Ruk/CIN85 molecular forms with different subcellular compartments was demonstrated. Induction of apoptosis of MCF-7 cells by doxorubicin treatment or by serum deprivation resulted in the system changes of Ruk/CIN85 molecular forms intracellular localization as well as their ratio. The data obtained provide a new insight into potential physiological significance of Ruk/CIN85 molecular forms in the regulation of various cellular functions.

Key words: adaptor proteins, Ruk/CIN85, multiple molecular forms, MCF-7 cells, subcellular distribution, apoptosis.

$\mathrm{T}$ o understand precisely mechanisms that control the functioning of intracellular signalling networks downstream of activated cell-surface receptors, the information regarding the biological significance of different isoforms and products of post-translational modifications of distinct signalling proteins is required. Among the important components of intracellular signaling networks are adaptor/scaffold proteins. Per definition, these modular proteins usually lack catalytic activity and are often necessary for the full activation of signaling pathways. They determine formation and localization of signaling complexes and can support or inhibit signal transduction depending on their stoichiometry in particular compartments thus regulating signal specificity, efficiency and amplitude of signal propagation [1, 2].

The widely expressed multifunctional adaptor/scaffold protein Ruk (Regulator for ubiquitous kinase - in rodents) [3] and CIN85 (Cbl-interacting protein of $85 \mathrm{~K}$ - in human [4], thereafter Ruk/
CIN85, consists of several distinctive structural features including amino-terminal three SH3 domains followed by Pro- and Ser-rich regions and C-terminal coiled-coil domain. By utilizing distinct combinations of binding partners Ruk/CIN85 was found to play important roles in a plethora of processes such as rearrangement of actin cytoskeleton, cell adhesion and invasion [5-10], apoptosis [3, 11, 12], mitogenic signaling [10,13, 14], attenuation of ligand-activated receptor tyrosine kinases, vesicular trafficking [13-15], and viral infection [16]. Ruk/CIN85 is not the only protein product of the Sh3kbp1/SH3KBP1 gene. Different combinations of promoter usage and splicing events create multiple Sh3kbp1/SH3KBP1 transcripts in various tissues and cell lines, and expression of some of these transcripts is tightly regulated during development as well as differ in tissue distribution $[3,17]$. cDNAs encoding isoforms without the first N-terminal SH3 domain (SETA [11] and CD2BP3 [7]), two N-terminal SH3 domains ( Ruk $_{\mathrm{m}}$ $[3,17]$ and SH3KBP1 [18]), and the shortest Ruks 
isoform containing only coiled-coil region [17] have been cloned until now. However data of Finnis et al. [19] and our unpublished results suggest that additional splice variants remain to be discovered. There are data that intramolecular interactions keep Ruk/ CIN85 molecules in a 'closed' inactive conformation [7, 20], while oligomerization events between different Ruk/CIN85 isoforms can substantially increase its scaffolding potential resulting in specific outputs. It has been proposed that the biological activity of Ruk/CIN85 could be regulated by posttranslational modifications such as phosphorylation, ubiquitylation or SUMOylation [21-26] resulting in the appearance of additional Ruk/CIN85 molecular forms.

In the present study we demonstrate that Ruk/ CIN85 multiple molecular forms are differentially distributed between different subcellular compartments of human breast adenocarcinoma MCF-7 cells. Moreover, induction of apoptosis of MCF-7 cells by doxorubicin treatment or by serum deprivation leads to their specific redistribution suggesting the regulatory significance of this phenomenon.

\section{Materials and Methods}

Cell culture. Human breast adenocarcinoma MCF-7 cells were maintained in Dulbecco's modified Eagle's medium (DMEM), supplemented with $10 \%$ foetal calf serum, $2 \mathrm{mM} \mathrm{L-glutamine,} 50 \mathrm{U} /$ $\mathrm{ml}$ penicillin and $100 \mu \mathrm{g} / \mathrm{ml}$ streptomycin in a humidified atmosphere containing $5 \% \mathrm{CO}_{2}$ at $37^{\circ} \mathrm{C}$. For apoptosis induction, the cells were treated with doxorubicin $(10 \mu \mathrm{g} / \mathrm{ml})$ for $36 \mathrm{~h}$ or cultured in serum-free DMEM for $72 \mathrm{~h}$.

Cell viability assay. Cell viability was assessed by trypan blue dye exclusion. Shortly, cells were seeded in triplicate on 24-well plates $\left(1 \times 10^{4}\right.$ per well) and cultured for $12 \mathrm{~h}$. Then, various concentrations of doxorubicin (0.001, 0.01, 0.1, 1, 3, 5, 7, $10,100 \mu \mathrm{g} / \mathrm{ml}$ ) were added. After $36 \mathrm{~h}$ of culturing, cells were collected by trypsinization and counted in hemocytometer. The number of dead cells at each concentration point was estimated using trypan blue uptake test. The cytotoxicity of doxorubicin toward MCF-7 cells $\left(\mathrm{IC}_{50}\right.$ ) was calculated from dose response curves.

DNA-ladder. Cells were lysed in buffer containing $10 \mathrm{mM}$ Tris- $\mathrm{HCl}$ ( $\mathrm{pH}$ 8.0), $1 \mathrm{mM}$ EDTA and $0.2 \%$ Triton $\mathrm{X}-100$ for $10 \mathrm{~min}$ at $4^{\circ} \mathrm{C}$. The lysate was centrifuged at $14000 \mathrm{~g}$ for $20 \mathrm{~min}$ at $4{ }^{\circ} \mathrm{C}$. The supernatant containing low molecular weight DNA was incubated with RNAse A (70 $\mu \mathrm{g} / \mathrm{ml})$ for $1 \mathrm{~h}$ at $37^{\circ} \mathrm{C}$, treated with $0.5 \%$ SDS, and then incubated with proteinase $\mathrm{K}(150 \mu \mathrm{g} / \mathrm{ml})$ for $1 \mathrm{~h}$ at $50^{\circ} \mathrm{C}$. DNA was precipitated with isopropanol in the presence of $\mathrm{NaCl}$ and then dissolved in TE buffer containing $10 \mathrm{mM}$ Tris- $\mathrm{HCl}$ (pH 8.0), 1 mM EDTA. DNA samples were analyzed by electrophoresis in 1.5\% agarose gel. The gels were photographed upon ethidium bromide staining under UV light.

Preparation of cell lysates. To obtain total cell lysates, cells were lysed in buffer containing $50 \mathrm{mM}$ Tris- $\mathrm{HCl}$ (pH 6.8), 1 mM EDTA, 2\% SDS for $5 \mathrm{~min}$ at $95^{\circ} \mathrm{C}$. To obtain detergent-soluble and detergentinsoluble cellular fractions, cells were lysed, by mechanically triturated through a $1 \mathrm{ml}$ syringe, in lysis buffer containing $10 \mathrm{mM}$ Tris- $\mathrm{HCl}$ (pH 7.5), $150 \mathrm{mM}$ $\mathrm{NaCl}, 1 \%$ NP-40, 5 mM EDTA, $50 \mathrm{mM} \mathrm{NaF}, 1 \mathrm{mM}$ $\mathrm{Na}_{3} \mathrm{VO}_{4}, 5 \mathrm{mM}$ benzamidine, $1 \mathrm{mM}$ PMSF, $10 \mu \mathrm{g} /$ ml aprotinin, $10 \mu \mathrm{g} / \mathrm{ml}$ leupeptin, $1 \mu \mathrm{g} / \mathrm{ml}$ pepstatin, and kept on ice for 20 min. NP-40-soluble and NP40-insoluble fractions were resolved by centrifugation at $14000 \mathrm{~g}$ for $30 \mathrm{~min}$ at $4{ }^{\circ} \mathrm{C}$. The pellet (detergent-insoluble cellular fraction) was dissolved in buffer containing $50 \mathrm{mM}$ Tris- $\mathrm{HCl}$ (pH 6.8), $1 \mathrm{mM}$ EDTA, $2 \%$ SDS for 5 min at $95^{\circ} \mathrm{C}$.

Preparation of Subcellular Fractions. Cells were lysed in hypotonic buffer containing $0.4 \%$ NP-40, $10 \mathrm{mM}$ HEPES (pH 7.9), $1.5 \mathrm{mM} \mathrm{MgCl}$, $10 \mathrm{mM} \mathrm{KCl}, 1 \mathrm{mM} \mathrm{Na} \mathrm{VO}_{4}, 5 \mathrm{mM}$ benzamidine, $1 \mathrm{mM}$ PMSF, $10 \mu \mathrm{g} / \mathrm{ml}$ aprotinin, $10 \mu \mathrm{g} / \mathrm{ml}$ leupeptin, $1 \mu \mathrm{g} / \mathrm{ml}$ pepstatin for $15 \mathrm{~min}$ at $4{ }^{\circ} \mathrm{C}$ followed by centrifugation at $3000 \mathrm{rpm}$ for $15 \mathrm{~min}$ at $4{ }^{\circ} \mathrm{C}$. Equal volume of $2 \mathrm{x}$ lysis buffer was added to the supernatant (crude cytoplasmic fraction) while nuclear pellet was directly lysed in lysis buffer. Both lysates were kept on ice for $20 \mathrm{~min}$ and then centrifuged at $14000 \mathrm{~g}$ for $30 \mathrm{~min}$. The supernatants were collected giving NP-40-soluble 'cytosolic fraction' and NP-40-soluble 'nuclear fraction' while precipitates were dissolved as indicated above giving NP-40-insoluble 'cytosolic fraction' and NP-40-insoluble 'nuclear fraction' accordingly. Chromatin-associated proteins were extracted from NP-40-insoluble nuclear fraction by incubation in low-salt buffer containing $0.5 \mathrm{M} \mathrm{NaCl}, 10 \mathrm{mM}$ Tris- $\mathrm{HCl}$ (pH 7.5), $5 \mathrm{mM}$ EDTA, $1 \mathrm{mM} \mathrm{Na} \mathrm{VO}_{4}, 5 \mathrm{mM}$ benzamidine, $1 \mathrm{mM}$ PMSF, $10 \mu \mathrm{g} / \mathrm{ml}$ aprotinin, $10 \mu \mathrm{g} / \mathrm{ml}$ leupeptin, $1 \mu \mathrm{g} / \mathrm{ml}$ pepstatin). The pellet (fraction of nuclear matrix-associated proteins) was dissolved in buffer containing $50 \mathrm{mM}$ Tris-HCl (pH 6.8), $1 \mathrm{mM}$ EDTA, $2 \%$ SDS for $5 \mathrm{~min}$ at $95^{\circ} \mathrm{C}$. 
Preparation of Nuclear Envelope Fraction. Fraction of nuclear envelopes was isolated as reported [27] with several modifications. Briefly, cells were lysed in hypotonic buffer containing 0.4\% NP-40, $10 \mathrm{mM}$ HEPES (pH 7.9), $1.5 \mathrm{mM} \mathrm{MgCl}_{2}, 10 \mathrm{mM}$ $\mathrm{KCl}, 1 \mathrm{mM} \mathrm{Na} \mathrm{VO}_{4}, 5 \mathrm{mM}$ benzamidine, $1 \mathrm{mM}$ PMSF, $10 \mu \mathrm{g} / \mathrm{ml}$ aprotinin, $10 \mu \mathrm{g} / \mathrm{ml}$ leupeptin, $1 \mu \mathrm{g} /$ $\mathrm{ml}$ pepstatin for $15 \mathrm{~min}$ at $4{ }^{\circ} \mathrm{C}$. After centrifugation at $3000 \mathrm{rpm}$ for $15 \mathrm{~min}$, the pelleted nuclei were resuspended in $0.1 \mathrm{mM} \mathrm{MgCl}, 1 \mathrm{mM}$ DTT, $0.1 \mathrm{mM}$ PMSF. After addition of solution A containing 10\% sucrose, $20 \mathrm{mM}$ Tris- $\mathrm{HCl}$ ( $\mathrm{pH} 8.5$ ), $0.1 \mathrm{mM} \mathrm{MgCl}$, $1 \mathrm{mM}$ DTT, $0.1 \mathrm{mM}$ PMSF, $20 \mu \mathrm{g} / \mathrm{ml}$ DNAase I, $10 \mu \mathrm{g} / \mathrm{ml}$ RNAase A, the sample was incubated for $15 \mathrm{~min}$ at RT. Then, the solution B containing 30\% sucrose, $20 \mathrm{mM}$ Tris- $\mathrm{HCl}$ ( $\mathrm{pH} 7.5$ ), $0.1 \mathrm{mM} \mathrm{MgCl}$, $1 \mathrm{mM}$ DTT, $0.1 \mathrm{mM}$ PMSF was underlayed and the sample was centrifuged at $13000 \mathrm{~g}$ for $20 \mathrm{~min}$ at $4{ }^{\circ} \mathrm{C}$. The pellet was resuspended in solution $\mathrm{A}$ and treated once more as indicated above. The pelleted nuclear envelopes were dissolved in buffer containing $50 \mathrm{mM}$ Tris- $\mathrm{HCl}$ (pH 6.8), 1 mM EDTA, 2\% SDS for 5 min at $95^{\circ} \mathrm{C}$.

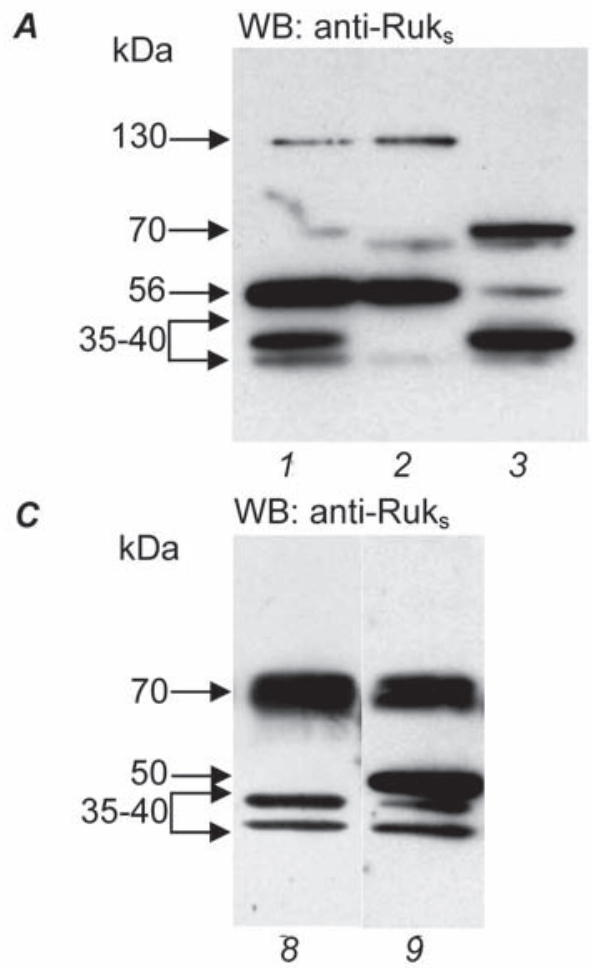

SDS-PAGE and Western-blot analysis. Protein fractions (50 $\mu$ g per sample) were separated on 5-18\% SDS-polyacrylamide gel and transferred to nitrocellulose membranes. Membranes were blocked with $5 \%$ non-fat dry milk in phosphate buffered saline with $0.05 \%$ Tween-20 (PBST), incubated with a primary rabbit polyclonal anti-Ruk $\mathrm{s}_{\mathrm{s}}$ antibodies [28] overnight at $4{ }^{\circ} \mathrm{C}$, and peroxidase-conjugated secondary goat anti-rabbit IgG antibodies (Sigma, USA) for $1 \mathrm{~h}$ at RT. The immunoreactive bands were detected using enhanced chemiluminescence (ECL) system (Amersham Biosciences, USA).

Statistics. Each data point to dose-response curve of cytotoxic assay is the mean \pm S.D. values based on $n=3$ independent samples.

\section{Results and Discussion}

Ruk/CIN85 multiple molecular forms are differentially distributed between MCF-7 subcellular fractions. In order to find regularity pattern of Ruk/CIN85 multiple molecular forms distribution between different subcellular fractions (see protocol) in MCF-7 cells under stationary conditions,

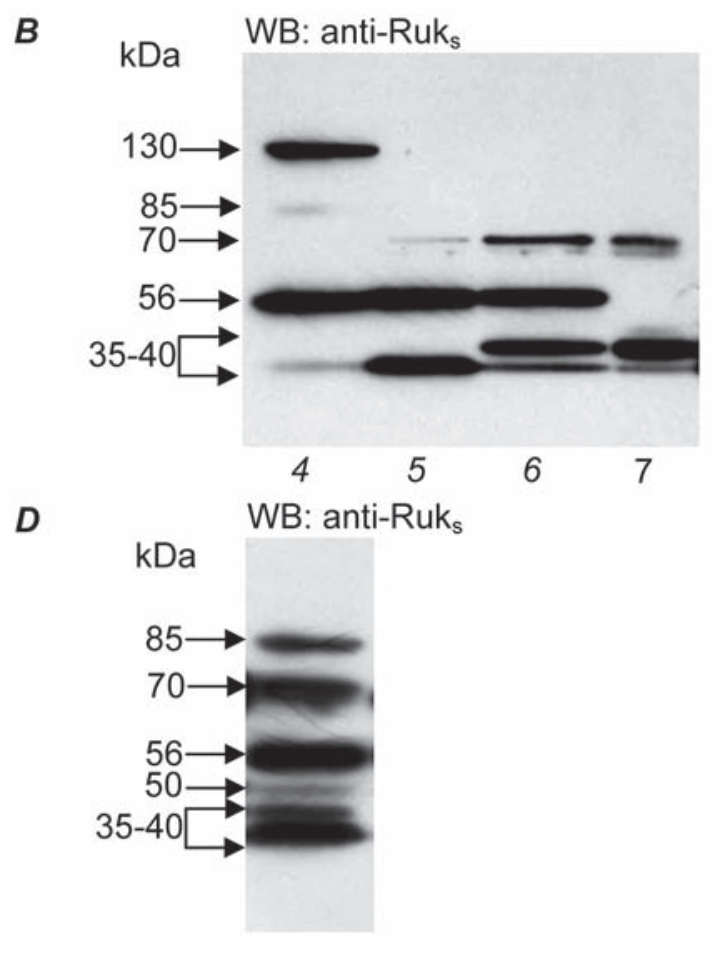

Fig. 1. Ruk/CIN85 multiple molecular forms are differentially distributed between MCF-7 subcellular fractions. (A) total cellular fractions (1 - total cell lysate, 2 - NP-40-soluble cellular fraction, 3 - NP-40-insoluble cellular fraction); (B) subcellular fractions (4 - NP-40-soluble 'cytoplasmic fraction'; 5 - NP-40-insoluble 'cytoplasmic fraction'; 6 - NP-40-soluble 'nuclear fraction'; 7 - NP-40-insoluble 'nuclear fraction'), (C) fractions of chromatin- (8) and nuclear matrix-associated proteins (9), and (D) nuclear envelope fraction 
we performed Western-blot analysis using rabbit polyclonal anti-Ruk ${ }_{\mathrm{s}}$ antibodies that recognise common to all molecular forms C-terminal coiled-coil region [28]. As can been seen from Fig. 1, multiple immunoreactive bands that correspond to proteins with apparent molecular weights of 130, 70, 56 and 35-40 kDa were revealed in total cell lysate. It is important to note that forms of 130 and $56 \mathrm{kDa}$ are mainly detected in detergent-soluble fraction, while forms with apparent molecular weights of 70 and 35-40 kDa dominate in detergent-insoluble cellular fraction. These data demonstrate specific allocation of Ruk/CIN85 molecular forms between detergentsoluble and detergent-insoluble cellular fractions.

To perform the more precise analysis of Ruk/ CIN85 multiple forms subcellular distribution, MCF-7 cells lysed in hypotonic buffer were fractionated into crude cytoplasmic and nuclear compartments which were further lysed separately to generate NP-40-soluble 'cytoplasmic fraction' (which mainly contains proteins of cytosol and cell membranes), NP-40-insoluble 'cytoplasmic fraction' (predominantly proteins of cell cytoskeleton), NP-40-soluble 'nuclear fraction' (mainly proteins of nucleoplasm and nuclear membranes) and NP-40-insoluble 'nuclear fraction' (fraction of nuclear matrixand chromatin-associated proteins) [29].

It was shown (Fig. 1, A) that Ruk/CIN85 form of $130 \mathrm{kDa}$ is present only in NP-40-soluble cytoplasmic fraction, which agrees with Ruk/CIN85 pattern in MCF-7 detergent-soluble fraction. Ruk/ CIN85 full-length form of $85 \mathrm{kDa}$, which is not detected in MCF-7 total cell lysate, is revealed at the very low level in NP-40-soluble cytoplasmic fraction only (Fig. 1, B). These results argue in favour of preferential localization of Ruk/CIN85 130 and $85 \mathrm{kDa}$ forms in cell cytosolic compartment. In contrast, form with apparent molecular weight of $70 \mathrm{kDa}$ is localized in nuclear compartment, where it is equally distributed between detergent-soluble and detergent-insoluble 'nuclear fractions'. Simultaneously, a very low amount of p70 was revealed in NP-40-insoluble ‘cytoplasmic fraction' (Fig. 1, B). The obtained data suggest possible localization of p70 Ruk/CIN85 form in nucleoplasm as well as its association with proteins of chromatin/nuclear matrix and cell cytoskeleton. Molecular form of $56 \mathrm{kDa}$ is detected in both cytoplasmic fractions as well as in NP-40-soluble 'nuclear fraction' while it is completely absent in NP-40-insoluble 'nuclear fraction' (Fig. 1, B). These features reflect preferential cytosol- ic and nucleoplasmic location of p56 as well as its association with proteins of cell cytoskeleton. The immunoreactive bands that correspond to Ruk/CIN85 forms of 35-40 kDa are present in all subcellular fractions studied (Fig. 1, B). At the same time, form of $35 \mathrm{kDa}$ is mainly detected in NP-40-insoluble 'cytoplasmic fraction'. In contrast, form of $40 \mathrm{kDa}$ is equally distributed between detergent-soluble and -insoluble 'nuclear fractions'. These results indicate that Ruk/CIN85 form of $35 \mathrm{kDa}$ is preferentially distributed in cytoplasmic compartment and is mainly associated with proteins of cell cytoskeleton, while form of $40 \mathrm{kDa}$ is representative of nuclear compartment where it is localized in nucleoplasm and associated with proteins of chromatin/nuclear matrix.

The spectrum of Ruk/CIN85 multiple molecular forms revealed in detergent-soluble fraction of MCF-7 cells is similar to our previous Western-blot analysis with C-terminal antibodies using as a model cell lines of various tissue origins [28]. It was suggested that some of these forms encoded by the specific spliced mRNAs correspond to the full-length form $-\mathrm{p} 85$, to the form without first SH3A domain $\mathrm{p} 70$, to the form without two SH3AB domains - p56, while p16 represents the form containing C-terminal coiled-coil domain. In addition, the form of $130 \mathrm{kDa}$ may be a result of post-translational modification of full-length form through ubiquitylation [21, 22] and 35-40 kDa forms may arise from limited proteolysis caused by the presence of PEST-motifs in C-terminal half of polypeptide chain [3]. To date, the evidences that Ruk/CIN85 is phosphorylated have been reported [24-26]. Therefore, this allows us to suppose that subforms around indicated molecular weights are mainly the result of post-translational modifications of Ruk/CIN85 through phosphorylation.

To study in detail Ruk/CIN85 subnuclear distribution, the stepwise extraction of chromatinassociated proteins and nuclear matrix-associated proteins was performed. It was demonstrated that Ruk/CIN85 forms of 70 and 35-40 kDa are detected in fractions of both chromatin- and nuclear matrixassociated proteins. In fraction of nuclear matrixassociated proteins, form of $50 \mathrm{kDa}$, absent in other MCF-7 fractions, is revealed (Fig. 1, C). This argues in favour of p50 association with nuclear scaffold proteins [29].

Since the obtained data demonstrate distribution of Ruk/CIN85 multiple molecular forms between cytoplasmic and nuclear fractions, it appears that they must shuttle between these cellular com- 
partments. In order to check this assumption, the investigation of Ruk/CIN85 molecular forms pattern in the nuclear envelope was performed. Under the isolation protocol used, the nuclear envelope consists of outer nuclear membrane continuous with the rough endoplasmic reticulum, inner nuclear membrane and pore membrane domains. Surprisingly, the greatest number of Ruk/CIN85 molecular forms (85, $70,56,50$ and $35-40 \mathrm{kDa}$ ) was revealed in the fraction of nuclear envelopes in comparison with other subcellular fractions studied (Fig. 1, D). We also showed that in MCF-7 cells the main pool of Ruk/ CIN85 full-length form of $85 \mathrm{kDa}$ is associated with fraction of nuclear envelopes that was not reported so far.

Apoptosis of MCF-7 cells induced by doxorubicin or serum deprivation results in subcellular redistribution of Ruk/CIN85 multiple molecular forms. Taking into account the above results and experimental data regarding the role of Ruk/CIN85 in apoptosis [3, 11, 12], we next sought to determine whether subcellular localization of Ruk/CIN85 molecular forms is regulated in the course of programmed cell death.

Apoptosis in MCF-7 cells was induced by doxorubicin treatment $(10 \mu \mathrm{g} / \mathrm{ml})$ for $36 \mathrm{~h}$ or by serum deprivation for $72 \mathrm{~h}$. Apoptosis induction in MCF-7 cells was confirmed by DNA-ladder technique. As could be seen from Fig. 2, DNA fragmentation is detected in MCF-7 cells treated with doxorubicin and cultured in serum-free medium but not in control cells. It should be noted that DNA hydrolysis in MCF-7 cells fails to undergo typical DNA-ladder pattern because of caspase-3 deficiency [30].

The results of Western-blotting presented on Fig. 3, A demonstrate that doxorubicin-induced apoptosis leads both to changes in ratio between different Ruk/CIN85 molecular forms and their redistribution between MCF-7 subcellular fractions. In apoptotic cells, the content of $130 \mathrm{kDa}$ form is down-regulated in comparison with control MCF-7 cells. Importantly, Ruk/CIN85 form of $70 \mathrm{kDa}$ is not detected in any subcellular fraction studied. Although the level of $56 \mathrm{kDa}$ form is up-regulated in apoptotic cells, this form is not detected in the fraction of cytoskeleton-associated proteins in contrast to control MCF-7 cells. Doxorubicin-induced apoptosis also triggers up-regulation of Ruk/CIN85 form with apparent molecular weight of $50 \mathrm{kDa}$ but, as in the control cells, this form is still detected in fraction of nuclear matrix-associated proteins. The content of

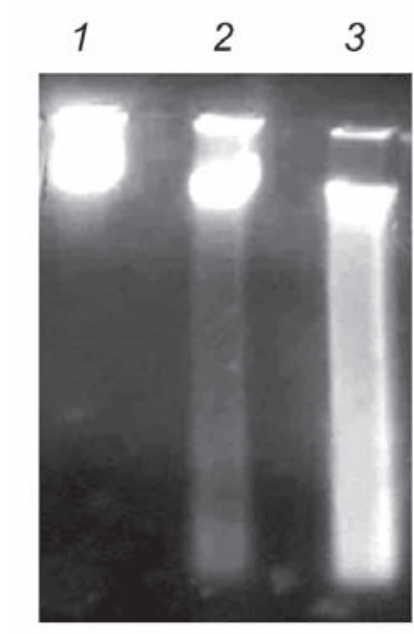

Fig. 2. Doxorubicin- and starvation-induced apoptosis of MCF-7 cells lead to DNA fragmentation: 1 - control MCF-7 cells; 2 - MCF-7 cells cultured in serum-deprived medium for $72 \mathrm{~h} ; 3$-cells treated with doxorubicin $(10 \mu \mathrm{g} / \mathrm{ml})$ for $36 \mathrm{~h}$

35-40 kDa forms is elevated in cytoplasmic and nucleoplasmic compartments and remains unchangeable in other subcellular fractions studied.

By contrast, serum starvation-induced apoptosis does not influence the overall Ruk/CIN85 spectrum but triggers changes in the content and subcellular location of some molecular forms (Fig. 3, B). First, form of $70 \mathrm{kDa}$ is translocated from fractions of nuclear compartment to fraction of cytoskeleton-associated proteins in comparison with control MCF-7 cells. In apoptotic cells, the level of 56 $\mathrm{kDa}$ Ruk/CIN85 form is elevated and in contrast to MCF-7 control cells, where this form is detected both in cytoplasmic and nucleoplasmic compartments, this form also appears to be associated with proteins of nuclear matrix. Starvation-induced apoptosis also leads to the up-regulation of Ruk/CIN85 forms of 35-40 and 50 kDa but does not influence their subcellular distribution.

Altogether, we have demonstrated for the first time that each subcellular compartment of human breast adenocarcinona MCF-7 cells is characterized by specific pattern of Ruk/CIN85 molecular forms. Cytosolic compartment is characterized by the presence of 130 and $56 \mathrm{kDa}$ forms. Molecular forms of 56 and 35-40 kDa are associated with proteins of cell cytoskeleton. In putative nucleoplasmic compartment Ruk/CIN85 forms of 70, 56 and 35-40 kDa are revealed. Molecular forms of 70 and $35-40 \mathrm{kDa}$ are detected in fraction of chromatin-associated pro- 
$\boldsymbol{A}$

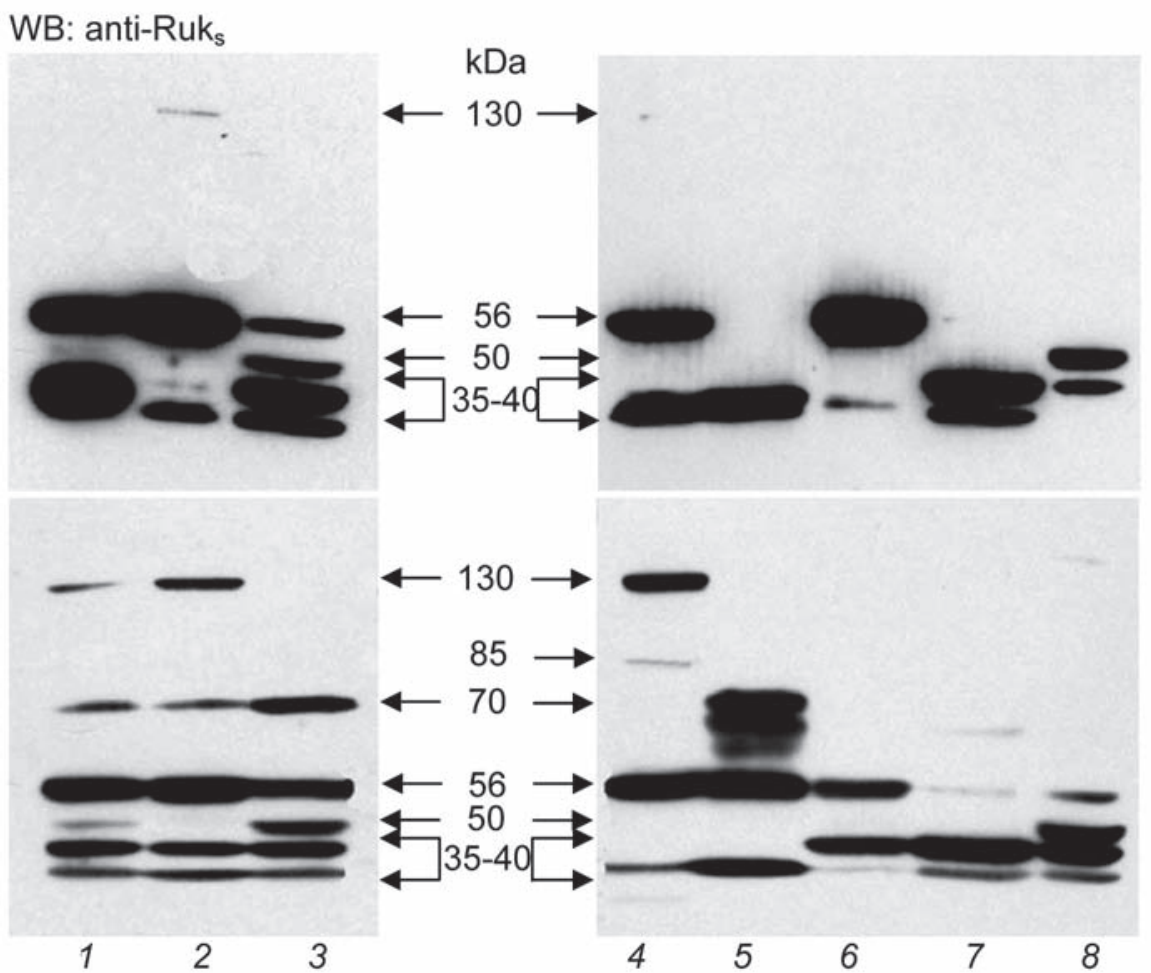

Fig. 3. Apoptosis of MCF-7 cells induced by doxorubicin or serum deprivation results in subcellular redistribution of Ruk/CIN85 multiple molecular forms. (A) Doxorubicin-induced apoptosis. (B) Serum starvationinduced apoptosis: 1 - total cell lysate; 2 - NP-40-soluble cellular fraction; 3 -NP-40-insoluble cellular fraction; 4 - NP-40-soluble 'cytoplasmic fraction'; 5 - NP-40-insoluble 'cytoplasmic fraction'; 6 - NP-40-soluble 'nuclear fraction'; 7 - NP-40-'insoluble nuclear fraction'; nuclear envelope fraction

teins, while forms of 70, 50 and 35-40 kDa are associated with proteins of nuclear matrix. The most broad molecular forms spectrum and the highest level of Ruk/CIN85 full-length form are characteristic of the fraction of nuclear envelopes. Although we were able to identify differential compartmentalization of Ruk/CIN85 multiple molecular forms in the nucleus, their exact biological role in the nuclear processes remains to be elucidated.

Our findings also clearly demonstrate that induction of apoptosis in MCF-7 cells triggers changes in the content and subcellular distribution of Ruk/ CIN85 molecular forms. Importantly, these changes are unique for each form under different types of apoptosis. Doxorubicin-induced apoptosis leads to up- regulation of Ruk/CIN85 molecular forms of 56, 50 and 35-40 kDa, down-regulation of 130 and $70 \mathrm{kDa}$ forms and disappearance of $56 \mathrm{kDa}$ molecular form from fraction of cytoskeleton-associated proteins in comparison with control MCF-7 cells. Serum-deprived apoptosis is accompanied by translocation of $70 \mathrm{kDa}$ form from fractions of cell nuclei to fraction of cytoskeleton-associated proteins, association of $56 \mathrm{kDa}$ with proteins of nuclear matrix and increase of 50 and 35-40 kDa Ruk/CIN85 forms content.

Results from our study provide a new mechanistic insights into potential specific physiological roles of adaptor protein Ruk/CIN85 molecular forms in signalling networks involved in the control of cell responses. 
МНОЖИННІ МОЛЕКУЛЯРНІ ФОРМИ

АДАПТЕРНОГО ПРОТЕЇНУ Ruk/

CIN85 СПЕЦИФІЧНО АСОЦІЙОВАНІ

3 РІЗНИМИ СУБКЛІТИННИМИ

КОМПАРТМЕНТАМИ

В АДЕНОКАРЦИНОМНИХ

КЛІТИНАХ МОЛОЧНОЇ ЗАЛОЗИ ЛЮДИНИ МСЕ-7

\section{Б. О. Виннитська-Мироновська ${ }^{1}$, Я. П. Бобак 1 , Г. В. Пасічник ${ }^{2}$, \\ Н. I. Ігуменцева ${ }^{1}$, А. А. Самойленко ${ }^{2}$, Л. Б. Дробот ${ }^{2}$}

${ }^{1}$ Інститут біології клітини НАН України, Львів;

${ }^{2}$ Інститут біохімії ім. О. В. Палладіна

НАН України, Київ;

e-mail: drobot@biochem.kiev.ua

Ruk/CIN85 є проксимально розташованим по відношенню до рецепторів «сигнальним» адаптером, до складу якого входять $3 \mathrm{SH} 3$ домени, Pro- i Ser-багаті райони, а також С-кінцевий «coiled-coil» домен. Завдяки використанню різних доменів і мотивів Ruk/CIN85 функціонує як платформа для перетворення сигналів у механізмах внутрішньоклітинного сигналювання. На основі аналізу кДНК були виявлені ізоформи Ruk/CIN85 iз різною комбінацією доменів, залучених до протеїн-протеїнових взаємодій. Показано існування додаткових форм, які $\epsilon$ продуктами посттрансляційних модифікацій. Однак до цього часу в літературі відсутня точна інформація щодо субклітинного розподілу множинних молекулярних форм Ruk/CIN85 i їх ролі в клітинних відповідях. На моделі аденокарциномних клітин молочної залози людини MCF-7 і з застосуванням низки методичних підходів для фракціонування клітин була показана специфічна асоціація молекулярних форм Ruk/CIN85 із різними субклітинними компартментами. Індукція апоптозу клітин MCF-7 обробкою доксорубіцином або культивуванням за відсутності сироватки призводила як до системних змін внутрішньоклітинної локалізації молекулярних форм Ruk/CIN85, так i до змін їх співвідношення. Одержані дані дозволяють по-новому підійти до оцінки потенційної фізіологічної значимості молекулярних форм Ruk/CIN85 в регуляції різних клітинних функцій.
Кл юч о в і с лов а: адаптерні протеїни, $\mathrm{Ruk} / \mathrm{CIN85,} \mathrm{множинні} \mathrm{молекулярні} \mathrm{форми,}$ клітини MCF-7, субклітинний розподіл, апоптоз.

\section{МНОЖЕСТВЕННЫЕ \\ МОЛЕКУЛЯРНЫЕ ФОРМЫ \\ АДАПТЕРНОГО ПРОТЕИНА \\ Ruk/CIN85 CПЕЦИФИЧЕСКИ \\ АССОЦИИРОВАНЫ С РАЗНЫМИ \\ СУБКЛЕТОЧНЫМИ \\ КОМПАРТМЕНТАМИ \\ В АДЕНОКАРЦИНОМНЫХ КЛЕТКАХ \\ МОЛОЧНОЙ ЖЕЛЕЗЫ ЧЕЛОВЕКА \\ MCF-7}
Б. О. Виннитская-Мироновская ${ }^{1}$,
Я. П. Бобакำ А. В. Пасечник ${ }^{2}$,
Н. И. Игуменцева ${ }^{1}$, А. А. Самойленко ${ }^{2}$,
Л. Б. Дробот ${ }^{2}$

${ }^{1}$ Институт биологии клетки НАН Украины, Львов;

${ }^{2}$ Институт биохимии им. А. В. Палладина

НАН Украины, Киев;

e-mail: drobot@biochem.kiev.ua

Ruk/CIN85 является проксимально расположенным по отношению к рецепторам «сигнальным» адаптером, в состав которого входят 3 SH3 домена, Pro- и Ser-богатые районы, а также С-концевой «coiled-coil» домен. Благодаря использованию различных доменов и мотивов Ruk/CIN85 функционирует в качестве преобразующей платформы в механизмах внутриклеточной сигнализации. На основе анализа кДНК были выявлены изоформы Ruk/CIN85 с различной комбинацией доменов, вовлеченных в протеиново-протеиновые взаимодействия. Показано существование дополнительных форм, которые являются продуктами посттрансляционных модификаций. Однако к настоящему времени в литературе отсутствует точная информация о субклеточном распределении множественных молекулярных форм Ruk/CIN85 и их роли в клеточных ответах. На модели аденокарциномных клеток молочной железы человека MCF-7, с применением ряда методических подходов для фракционирования клеток была показана специфическая ассоциация молекулярных форм Ruk/CIN85 с различными субклеточными компартментами. Индукция апоптоза клеток MCF-7 обработкой доксорубицином или культи- 
вированием в отсутствие сыворотки приводила как к системным изменениям внутриклеточной локализации молекулярных форм Ruk/CIN85, так и к изменениям их соотношения. Полученные данные позволяют по новому оценить потенциальную физиологическую значимость молекулярных форм Ruk/CIN85 в регуляции различных клеточных функций.

К л ю че в ы е с ло в а: адаптерные протеины, Ruk/CIN85, множественные молекулярные формы, клетки MCF-7, субклеточное распределение, апоптоз.

\section{References}

1. Levchenko A., Bruck J., Sternberg P. W. Scaffold proteins may biphasically affect the levels of mitogen-activated protein kinase signaling and reduce its threshold properties. Proc. Natl. Acad. Sci. USA. 2000;97(11):5818-5823.

2. Pawson T. Dynamic control of signaling by modular adaptor proteins. Curr. Opin. Cell Biol. 2007;19(2):112-116.

3. Gout I., Middleton G., Adu J., Ninkina N. N., Drobot L. B., Filonenko V., Matsuka G., Davies A. M., Waterfield M., Buchman V. L. Negative regulation of PI-3 kinase by Ruk, a novel adaptor protein. EMBO J. 2000;19(15):40154025.

4. Take H., Watanabe S., Takeda K., Yu Z. X., Iwata N., Kajigaya S. Cloning and characterization of a novel adaptor protein, CIN85, that interacts with c-Cbl. Biochem. Biophys. Res. Commun. 2000;268(2):321-328.

5. Hutchings N. J., Clarkson N., Chalkley R., Barclay A. N., Brown M. H. Linking the T cell surface protein CD2 to the actin-capping protein CAPZ via CMS and CIN85. J. Biol. Chem. 2003;278(25):22396-22403.

6. Schmidt M. H., Chen B., Randazzo L. M., Bogler O. SETA/CIN85/Ruk and its binding partner AIP1 associate with diverse cytoskeletal elements, including FAKs, and modulate cell adhesion. J. Cell Sci. 2003;116(14):2845-2855.

7. Tibaldi E. V., Reinherz E. L. CD2BP3, CIN85 and the structurally related adaptor protein CMS bind to the same CD2 cytoplasmic segment, but elicit divergent functional activities. Int. Immunol. 2003;15(3):313-329.

8. Nam J. M., Onodera Y., Mazaki Y., Miyoshi H., Hashimoto S., Sabe H. CIN85, a Cbl-interacting protein, is a component of AMAP1-mediated breast cancer invasion machinery. EMBO J. 2007;26(3):647-656.

9. Havrylov S., Redowicz M. J., Buchman V. L. Emerging roles of Ruk/CIN85 in vesiclemediated transport, adhesion, migration and malignancy. Traffic. 2010;11(6):721-731.

10. Samoylenko A., Vynnytska-Myronovska B., Byts N., Kozlova N., Basaraba O., Pasichnyk G., Palyvoda K., Bobak Y., Barska M., Mayevska O., Rzhepetsky Y., Shuvayeva H., Lyzogubov V., Usenko V., Savran V., Volodko N., Buchman V., Kietzmann T, Drobot L. Increased levels of the HER1 adaptor protein Rukl/CIN85 contribute to breast cancer malignancy. Carcinogenesis. 2012;33(10):1976-1984.

11. Chen B., Borinstein S. C., Gillis J., Sykes V. W., Bogler O. The glioma-associated protein SETA interacts with AIP1/Alix and ALG-2 and modulates apoptosis in astrocytes. J. Biol. Chem. 2000;275(25):19275-19281.

12. Narita T., Nishimura T., Yoshizaki K., Taniyama T. CIN85 associates with TNF receptor 1 via Src and modulates TNF- $\alpha$-induced apoptosis. Exp. Cell Res. 2005;304:256-264.

13. Petrelli A., Gilestro G. F., Lanzardo S., Comoglio P. M., Migone N., Giordano S. The endophilin-CIN85-Cbl complex mediates ligand-dependent downregulation of c-Met. Nature. 2002;416(6877):187-190.

14. Soubeyran P., Kowanetz K., Szymkiewicz I., Langdon W. Y., Dikic I. Cbl-CIN85endophilin complex mediates ligand-induced downregulation of EGF receptors. Nature. 2002;416(6877):183-187.

15. Havrylov S., Ichioka F., Powell K., Borthwick E. B., Baranska J., Maki M., Buchman V. L. Adaptor protein Ruk/CIN85 is associated with a subset of COPI-coated membranes of the Golgi complex. Traffic. 2008;9(5):798-812.

16. Narita T., Ando A., Mikami Yu., Taniyama T. Overexpression of CIN85 suppresses the growth of herpes simplex virus in HeLa cells. Exp. Cell. Res. 2005;311(2):265-271.

17. Buchman V. L., Luke C., Borthwick E. B., Gout I., Ninkina N. Organization of the mouse Ruk locus and expression of isoforms in mouse tissues. Gene. 2002;295(1):13-17.

18. Narita T., Amano F., Yoshizaki K., Nishimoto N., Nishimura T., Tajima T., Namiki H., Taniyama T. Assignment of SH3KBP1 to human chromosome band Xp22.1-\&gt;p21.3 by in situ hybridization. Cytogenet. Cell Genet. 2001;93(1-2):133-134. 
19. Finniss S., Movsisyan A., Billecke C., Schmidt M., Randazzo L., Chen B., Bögler O. Studying protein isoforms of the adaptor SETA/CIN85/ Ruk with monoclonal antibodies. Biochem. Biophys. Res. Commun. 2004;325(1):174-182.

20. Borthwick E. B., Korobko I. V., Luke C., Drel V. R., Fedyshyn Y. Y., Ninkina N., Drobot L. B., Buchman V. L. Multiple domains of Ruk/CIN85/SETA/CD2BP3 are involved in interaction with $\mathrm{p} 85 \alpha$ regulatory subunit of PI 3-kinase. J. Mol. Biol. 2004;343(4):1135-1146.

21. Haglund K., Shimokawa N., Szymkiewicz I., Dikic I. Cbl-directed monoubiquitination of CIN85 is involved in regulation of ligandinduced degradation of EGF receptors. Proc. Natl. Acad. Sci. USA. 2002;9(19):12191-12196.

22. Verdier F., Valovka T., Zhyvoloup A., Drobot L. B., Buchman V., Waterfield M., Gout I. Ruk is ubiquitinated but not degraded by the proteasome. Eur. J. Biochem. 2002;269(14):34023408.

23. Tossidou I., Niedenthal R., Klaus M., Teng B., Worthmann K., King B. L., Peterson K. J., Haller H., Schiffer M. CD2AP regulates SUMOylation of CIN85 in podocytes. Mol. Cell Biol. 2012;32(6):1068-1079.

24. Rzepetskyi Y. A., Samoylenko A. A., Kucharenko O. P., Mikhalap S. V., Sidorenko S. P., Hausser A., Drobot L. B. Protein kinase D interacts with adaptor protein Ruk/CIN85 and phosphorylates it. Studia Biologica. 2009;3(3):17-28.
25. Bior B. K., Ballif B. A. Dab1 stabilizes its interaction with CIN85 by suppressing CIN85 phosphorylation at serine 587. FEBS Lett. 2013;587(1):60-66.

26. Schroeder B., Srivatsan S., Shaw A., Billadeau D., McNiven M. A. CIN85 phosphorylation is essential for EGFR ubiquitination and sorting into multivesicular bodies. Mol. Biol. Cell. 2012;3(18):3602-3611.

27. Hallberg E., Kihlmark M. Nucleus and nuclear envelope: methods for preparation. ELS: Nature Publ Group, 2001.

28. Mayevska O., Shuvayeva H., Igumentseva N., Havrylov S., Basaraba O., Bobak Y., Barska M., Volod'ko N., Baranska J., Buchman V., Drobot L. Expression of adaptor protein Ruk/CIN85 isoforms in cell lines of various tissue origins and human melanoma. Exp. Oncol. 2006;28(4):275281.

29. Swarup G., Radha V. Nuclear matrix: methods of preparation. ELS: Nature Publ. Group, 2001.

30. Kagawa S., Gu J., Honda T., McDonnell J., Swisher S. G., Roth J. A., Fang B. Deficiency of caspase-3 in MCF7 cells blocks Bax-mediated nuclear fragmentation but not cell death. Clin. Cancer Res. 2001;7(5):1474-1480.

Received 10.07.2014 